\title{
The Urgency and Role of Emoji and PUEBI-Compliant Spelling Applications in Digital Communication to Minimize Misunderstanding Among Airlangga University Students
}

\author{
Walidil Afi ${ }^{1}$, Amanda Putri Setianingrum ${ }^{2}$, Bagas Respati Adjie ${ }^{3}$, Moses Glorino \\ Rumambo Pandin ${ }^{4}$ \\ Faculty of Humanities, Universitas Airlangga \\ 트alidil.afi-2020@ fib.unair.ac.id, ${ }^{2}$ amanda.putri.setianingrum-2020@fib.unair.ac.id, \\ ${ }^{3}$ bagas.respati.adjie-2020@ fib.unair.ac.id, ${ }^{3}$ moses.glorino@ fib.unair.ac.id \\ Faculty of Humanities, Universitas Airlangga \\ Dharmawangsa Dalam Selatan, Kampus B, Surabaya, 60286, East Java, Indonesia
}

(031) 5035676

*Corresponding author's email: walidil.afi-2020@ fib.unair.ac.id

\begin{abstract}
The existence of CMC (Computer-Mediated Communication) has influenced the pattern of human communication, which was initially face-to-face, to become more accessible by using electronic devices. So that the communication process can be carried out more flexibly even though they are separated by distance. However, communication through electronic devices has limitations in conveying messages and providing the opportunity for the recipient to understand the message because CMC (Computer-Mediated Communication) does not include nonverbal communication such as expressions and feelings. Therefore, communication through electronic devices depends on the use of language only. However, people tend to make language errors in digital communication such as omission or punctuation errors, spelling errors and inappropriate PUEBI, abbreviated words, and complex words to understand. These two conditions certainly impact the digital communication process because people are at risk of experiencing misunderstandings with different perceptions between the two. This research aims to determine the urgency and role of emoji and PUEBI-compliant spelling in digital communication among Airlangga University students. This research method is descriptive qualitative by applying the purposive sampling technique. The respondent's criteria are undergraduate students from Universitas Airlangga who have experience in digital communication. Data were collected through surveys and literature studies to obtain detailed information on the research topic. The results show that using emoji and good spelling is critical in digital communication because of limitations in
\end{abstract}


delivering nonverbal communication and semantic errors that affect misunderstandings between communicators and communicators. Emojis and spellings that match The General Guideline for Indonesian Spelling (Pedoman Umum Ejaan Bahasa Indonesia [PUEBI]) can clarify messages so that the intent can be adequately conveyed, change the tone or intonation of speech, channel and represent the sender's expression, and give an impression to the sender of the message.

Keywords: emoji, spelling, PUEBI, digital communication

\section{BACKGROUND}

Technology is growing and covers almost all aspects of human life today. So, it is undeniable that humans have progressed because of the convenience provided by developing technology, including social relations. Humans need to write letters and send them by pigeon or post, and it takes a long time to communicate or exchange information then. However, with the expansion of internet access and the development of means of communication, the current communication process can be more efficient even though there are significant distance differences. Internet access has been in for a long time in Indonesia and has been widely used. Internet users in 2021 experienced progress from the previous year with a total of 202.6 million users $-73.7 \%$ of the total population of Indonesia. In addition, as many as 195.3 million Indonesians use mobile phones to enjoy the internet network (Kompas. Com, 2021). Thus, it can be concluded that the use of the internet in Indonesia has been relatively massive.

CMC (Computer-Mediated Communication) is a communication process of two or more people using an intermediary computer or electronic devices. One form of CMC (Computer-Mediated Communication) implementation is social media, including WhatsApp, Facebook, Instagram, Twitter, Youtube, and email. CMC (Computer-Mediated Communication) is used for various purposes, such as exchanging information, communication between individuals, learning objectives (Amin, 2020). Zeng (in Putra \& Irwansyah, 2020) states that the current existence of computer-based communication has shifted face-to-face communication interactions between individuals. Along with technology development, the public has employed CMC (Computer-Mediated Communication), and its use among the community has increased. Data states that 170 million people use social media for 3 hours 14 minutes, the longest duration of internet usage in Indonesia (Kompas. Com, 2021). 
The existence of CMC facilitates the communication process even though people involved in communication are in a separate location (Putri, 2020). This condition makes the communication process more flexible and convenient because it is not limited by place and time. However, online communication cannot cover aspects of nonverbal communication so that the emotions or feelings experienced cannot be adequately conveyed (Nahwiyyah \& Dewi, 2020). The weakness of CMC also lies in the limitations of users in sending messages to other parties, and people have difficulty understanding and exploring messages sent by other people (Putri \& Irwansyah, 2020). This condition is risky to hamper the communication process because misunderstandings or differences in interpretation may occur. After all, the communicator's emotions, expressions, and tone of voice cannot be conveyed to the communicant. In addition, messages that are not conveyed properly, the use of abbreviations, and that ignore the use of enhanced spelling (EYD) can increase the risk of misunderstanding (Triantoro, 2019). This misunderstanding can then affect the relationship between individuals involved in communication.

The limitations of the text message feature in conveying messages in the online communication process or $\mathrm{CMC}$ require preventions to minimize misunderstandings between the individuals involved so that their relationship can be maintained. In CMC, various emojis are considered to be used to represent and express various emotions in showing the attitude or response of the communicator, as well as representing the text message conveyed (Berlianty, 2020). In addition, the use of proper spelling also needs to be used in the online communication process because messages conveyed with inappropriate grammar or linguistic rules will make it difficult for the communicant to understand the communicator's message and risk causing different interpretations between the two.

Based on the issues that have been described, the researcher conducted a study to determine the role or benefits and urgency of using emoji and good spelling based on The General Guideline for Indonesian Spelling (Pedoman Umum Ejaan Bahasa Indonesia [PUEBI]) in online communication to minimize misunderstandings among Airlangga University students. Later, the findings of this study are expected to provide understanding to the public, especially teenagers as the subject of this research; thus, they can interpret messages received in digital communication, pay attention to message delivery, and use emoji as a tool provided in communication media if needed. Therefore, communication can run smoothly and avoid any conflicts due to misunderstandings or differences in interpretation between communicants and communicators. 


\section{METHODS}

Researchers used qualitative descriptive methods, survey techniques, and literature studies to get a detailed description of the urgency and role or function of emojis and good spelling in digital communication to minimize misunderstandings. The survey consists of four open-ended questions that allow respondents to provide information or knowledge and experience regarding the research topic. The population of this study was undergraduate students at Universitas Airlangga.

The research sample was determined through the purposive sampling technique. This method is a way of determining the sample through the application of specific criteria or conditions to the population, or a technique used by researchers after determining the problem to be solved and recruiting people who can and are willing to provide information based on experience or knowledge (Bernard, 2002). The criteria determined are active students of the Airlangga University undergraduate program and students who are often involved in digital communication. Airlangga University students were chosen as representatives of the most social media connoisseurs in Indonesia based on the age category in 2020, namely the age range of 18-24 and 25-34 years (databoks.katadata.co.id, 2020).

This study utilizes both primary and secondary data as research references. Primary data is taken by distributing surveys to target respondents based on existing criteria. Meanwhile, secondary data comes from the literature appropriate to the research topic and is published in the 2019-2021 range. The literature obtained came from Google Scholar and other databases using the keywords "emoji", "spelling", "PUEBI", "digital communication", and "misunderstanding".

\section{RESULTS}

The survey that has been distributed has received responses/data from 98 respondents who meet the criteria. The data is then categorized based on the same keyword or code. The following is the result of grouping the data that has been collected. 
Tabel 1 The role of emoji in the digital communication process

\begin{tabular}{|c|c|c|c|c|}
\hline No & Question & $\begin{array}{l}\text { Response Type/ } \\
\text { Number of } \\
\text { Responses }(\%)\end{array}$ & Codes & $\begin{array}{l}\text { Number } \\
\text { of codes } \\
(\%)\end{array}$ \\
\hline \multirow[t]{12}{*}{1.} & \multirow{12}{*}{$\begin{array}{l}\text { Do you think that } \\
\text { using emojis can } \\
\text { help to convey } \\
\text { messages and reduce } \\
\text { misunderstandings in } \\
\text { communicating } \\
\text { digitally? Please } \\
\text { explain! }\end{array}$} & \multirow[t]{7}{*}{$\begin{array}{c}\text { Yes/ } \\
92,9 \%\end{array}$} & $\begin{array}{l}\text { Conveying } \\
\text { expressions/states/emotions }\end{array}$ & $46,1 \%$ \\
\hline & & & Conveying meaning/message & $25,2 \%$ \\
\hline & & & $\begin{array}{l}\text { Knowing the response of the } \\
\text { interlocutor }\end{array}$ & $1,7 \%$ \\
\hline & & & Giving perception to the message & $13 \%$ \\
\hline & & & Representing the tone of voice & $2,6 \%$ \\
\hline & & & $\begin{array}{l}\text { Understanding the direction of the } \\
\text { conversation }\end{array}$ & $0,9 \%$ \\
\hline & & & $\begin{array}{l}\text { Serving as a complementary / } \\
\text { explanation of the message }\end{array}$ & $4,3 \%$ \\
\hline & & \multirow[t]{5}{*}{$\mathrm{No} / 7,1 \%$} & Emoji function is not clear & $0,9 \%$ \\
\hline & & & $\begin{array}{l}\text { The ability of emoji to represent } \\
\text { the sender's message or feelings is } \\
\text { still lacking }\end{array}$ & $2,6 \%$ \\
\hline & & & $\begin{array}{l}\text { The use of emojis has not been } \\
\text { able to have an impact on the } \\
\text { communication process }\end{array}$ & $0,9 \%$ \\
\hline & & & $\begin{array}{lrr}\text { Different ways of } & \text { interpreting } \\
\text { emojis } & \text { allow } & \text { for } \\
\text { misunderstanding } & \end{array}$ & $0,9 \%$ \\
\hline & & & $\begin{array}{l}\text { Sending messages can still be } \\
\text { done without the use of emojis }\end{array}$ & $0,9 \%$ \\
\hline
\end{tabular}

Table 1 shows that $92.9 \%$ of the total respondents agree that emoji play a role in conveying messages well and reducing the risk of misunderstandings in digital communication. From the positive responses, most respondents $(46.1 \%)$ think that emojis can convey expressions, circumstances, or emotions during the digital communication process. In addition, respondents stated that emoji were able to help convey messages (25.2\%), knowing the response of interlocutors (1.7\%), giving perceptions of the message received (13\%), representing speech tone or intonation $(2.6 \%)$, and becomes a complement or additional 
explanation of the message (4.3\%). However, $7.1 \%$ of the respondents did not agree with the questions asked. Emoji are considered not to have a clear function for some people $(0.9 \%)$, have not been able to represent the feelings or messages of the sender as a whole (2.6\%), do not have a real effect on the communication process $(0.9 \%)$, are at risk cause misunderstandings due to differences in perceptions between individuals $(0.9 \%)$, and do not have an essential role in message delivery because the process of exchanging messages or communication can still be carried out even without emojis $(0.9 \%)$.

Tabel 2 The urgency of using emoji and PUEBI-compliant spelling in digital communication

\begin{tabular}{|c|c|c|c|c|}
\hline No & Question & $\begin{array}{l}\text { Response } \\
\text { Type/ } \\
\text { Number of } \\
\text { Responses } \\
(\%)\end{array}$ & Codes & $\begin{array}{l}\text { Number } \\
\text { of codes } \\
(\%)\end{array}$ \\
\hline \multirow[t]{7}{*}{1.} & \multirow{7}{*}{$\begin{array}{l}\text { Is the use of emojis and } \\
\text { PUEBI-compliant } \\
\text { spelling critical in digital } \\
\text { communications? Why? }\end{array}$} & \multirow{6}{*}{$\begin{array}{l}\text { Yes/ } \\
97,9 \%\end{array}$} & Putting intonation on the message & $4,6 \%$ \\
\hline & & & Clarifying message/context & $39,8 \%$ \\
\hline & & & $\begin{array}{l}\text { Helping to familiarize and } \\
\text { practice excellent and correct } \\
\text { language skills }\end{array}$ & $7,4 \%$ \\
\hline & & & Creating a good impression & $6,5 \%$ \\
\hline & & & Preventing misunderstanding & $28,7 \%$ \\
\hline & & & $\begin{array}{l}\text { Adjusting response based on } \\
\text { situation/needs and interlocutor }\end{array}$ & $11,1 \%$ \\
\hline & & $\mathrm{No} / 2,1 \%$ & $\begin{array}{l}\text { The information conveyed is more } \\
\text { important }\end{array}$ & $1,9 \%$ \\
\hline
\end{tabular}

Based on the table above, most respondents think that using emojis and the proper spelling based on PUEBI is vital in digital communication (97.9\%). Emoji and PUEBIcompliant spelling can clarify and emphasize the intent or message (39.8\%), avoid the risk of misunderstanding in digital communication $(28.7 \%)$, adjust responses to the other person and the situation of the communication being carried out $(11.1 \%)$, become a means to practice good language skills $(7.4 \%)$, create a positive impression to the interlocutor $(6.5 \%)$, and replace intonation in the message $(4.6 \%)$. However, some argue that emoji and proper spelling based on PUEBI are not very important as long as the message conveyed is wellreceived $(1.9 \%)$. 
Tabel 3 Conflicts in digital communication due to the use of incorrect spelling

\begin{tabular}{|c|c|c|c|c|}
\hline No & Question & $\begin{array}{c}\text { Response } \\
\text { Type/ Number } \\
\text { of Responses } \\
(\%)\end{array}$ & Codes & $\begin{array}{l}\text { Number } \\
\text { of codes } \\
(\%)\end{array}$ \\
\hline \multirow[t]{3}{*}{1.} & \multirow{3}{*}{$\begin{array}{l}\text { Have you ever experienced } \\
\text { problems such as conflicts } \\
\text { or misunderstandings in } \\
\text { digital communication due } \\
\text { to the use of bad spelling, } \\
\text { such as the use of } \\
\text { punctuation and capital } \\
\text { letters? Please explain! }\end{array}$} & \multirow[t]{2}{*}{$\begin{array}{c}\text { Yes/ } \\
86,7 \%\end{array}$} & $\begin{array}{l}\text { Misunderstood the message } \\
\text { received }\end{array}$ & $65,4 \%$ \\
\hline & & & $\begin{array}{lrr}\text { Confused } & \text { by } & \text { unclear and } \\
\text { difficult } & \text { to } & \text { understand } \\
\text { messages } & & \\
\end{array}$ & $34,6 \%$ \\
\hline & & $\begin{array}{c}\mathrm{No} / \\
13.3 \%\end{array}$ & - & - \\
\hline
\end{tabular}

As many as $86.7 \%$ of respondents admitted that they had experienced conflicts or misunderstandings when conducting digital communications due to poor spelling. The reason is the difference in perception of the message between the recipient and the sender (65.45), and the message is not clear and confusing, so the recipient has difficulty understanding the message (34.6\%).

Tabel 4 The role of emoji and PUEBI-compliant spelling on the sender's perception/impression

\begin{tabular}{|c|c|c|c|c|}
\hline No & Question & $\begin{array}{c}\text { Response } \\
\text { Type/ Number } \\
\text { of Responses } \\
(\%)\end{array}$ & Codes & $\begin{array}{c}\text { Number } \\
\text { of codes } \\
(\%)\end{array}$ \\
\hline 1. & $\begin{array}{l}\text { Do you think the use of } \\
\text { emojis and PUEBI- } \\
\text { compliant spellings such } \\
\text { as capital letters and } \\
\text { punctuation reflect or } \\
\text { give a particular } \\
\text { impression about the } \\
\text { interlocutor and the } \\
\text { message conveyed? } \\
\text { Please explain! (E.g., } \\
\text { sending messages }\end{array}$ & $\begin{array}{c}\text { Yes/ } \\
70,4 \%\end{array}$ & $\begin{array}{l}\text { Short messages, good spelling, } \\
\text { and or messages without } \\
\text { emojis give various } \\
\text { impressions that are less } \\
\text { friendly or less flexible such as } \\
\text { stiff, bitchy, indifferent, } \\
\text { formal, or assertive. }\end{array}$ & $26,5 \%$ \\
\hline
\end{tabular}




\begin{tabular}{|c|c|c|c|}
\hline \multirow[t]{11}{*}{$\begin{array}{l}\text { without emojis and using } \\
\text { spelling based on rigid } \\
\text { PUEBI gives the } \\
\text { impression that the } \\
\text { sender is unfriendly) }\end{array}$} & & & \\
\hline & & $\begin{array}{l}\text { The use of emoji can give a } \\
\text { good impression on the sender, } \\
\text { such as friendly and } \\
\text { considerate }\end{array}$ & $27,7 \%$ \\
\hline & & $\begin{array}{l}\text { Writing abbreviated words } \\
\text { gives a negative impression on } \\
\text { the sender }\end{array}$ & $3,6 \%$ \\
\hline & & $\begin{array}{l}\text { Intense use of capital letters } \\
\text { gives an unfavorable } \\
\text { impression such as lack of } \\
\text { flexibility and intense emotions } \\
\text { such as anger or irritation and } \\
\text { enthusiasm }\end{array}$ & $7,2 \%$ \\
\hline & & $\begin{array}{l}\text { Excessive or inappropriate use } \\
\text { of emoji gives a negative or } \\
\text { annoying impression }\end{array}$ & $2,4 \%$ \\
\hline & & $\begin{array}{l}\text { The use of emojis gives an idea } \\
\text { of how individuals } \\
\text { communicate }\end{array}$ & $2,4 \%$ \\
\hline & \multirow[t]{5}{*}{$\begin{array}{c}\mathrm{No} / \\
2,96 \%\end{array}$} & $\begin{array}{l}\text { Emoji cannot represent some } \\
\text { expressions }\end{array}$ & $1,2 \%$ \\
\hline & & $\begin{array}{l}\text { Emoji and language style can } \\
\text { not necessarily represent/ } \\
\text { reflect the personality of the } \\
\text { sender }\end{array}$ & $21,7 \%$ \\
\hline & & $\begin{array}{l}\text { There is no difference between } \\
\text { using emojis and good spelling } \\
\text { and not using them }\end{array}$ & $2,4 \%$ \\
\hline & & $\begin{array}{l}\text { Emojis are just a sweetener for } \\
\text { communication }\end{array}$ & $1,2 \%$ \\
\hline & & $\begin{array}{l}\text { Emojis are just individual } \\
\text { preference }\end{array}$ & $3,6 \%$ \\
\hline
\end{tabular}


Table 4 shows that $70.4 \%$ of the respondents agree that the use of particular spellings and emojis gives a specific impression. People who send short messages, spelled well, and do not include emojis are considered less flexible, less friendly, stiff, harsh, or assertive (26.5\%). In addition, short written words also give a negative impression to the sender (3.6\%), inappropriate use of capital gives the impression of intense emotions such as enthusiasm, anger, and annoyance (7.2\%), and excessive use of emoji makes the sender seems strange and annoying in the eyes of the recipient $(2.4 \%)$. However, some said that emojis could give a good impression on the sender, such as friendly, considerate, and humble $(27.7 \%)$, and the way someone communicated could be seen from the use of emojis (2.4\%).

On the other hand, some respondents think that emoji are still not able to represent some expressions (1.2\%), and there is no visible difference when using emojis and when using PUEBI-compliant spelling or not when communicating $(2.4 \%)$ because emoji in basically just a sweetener in communication (1.2\%). In addition, emoji and a person's language style do not necessarily reflect a person's personality and are used as a reference in assessing it $(21.7 \%)$ because emoji is a preference for each individual $(3.6 \%)$.

\section{DISCUSSION}

\section{Emoji}

Technological advances affect the way people communicate. The existence of CMC (Computer-Mediated Communication) is changing the way people establish relationships and communicate. Weiqan Wang (in Siregar et al., 2021) states that CMC (Computer-Mediated Communication) comes together with the emoji feature, a digital representation of facial expressions, and has been widely used by people in text messages as an alternative to the limitations of non-verbal language communication in a text message. Emojis are also considered as symbols whose use functions to show feelings, emotions, and activities that someone wants to inform in digital communication (Rakhman, 2020). Emoji can be utilized to represent expressions such as anger, sadness, and happiness (Hanafi, Basri, \& Hadijah, 2021). There are various emojis that users can use in digital communication. Until 2022, there are 3,460 emoji available and can be used by the public (Statista, 2021). Some examples of emojis are grinning face with sweat, face with tears of joy, rolling on the floor laughing, beaning face with smiling eyes, smiling with smiling eyes, smiling face with hello, hugging 
face, relieved face, smiling face with hearts, smiling with heart eyes, pleading face, face with hand over mouth, face screaming in fear, loudly crying face, face with rolling eyes, expressionless face, smiling face with sunglasses, slightly smiling face, thumbs up, and folded hands (Berlianty, 2020).

\section{PUEBI-Compliant Spelling}

The use of language in the communication process is vital to convey messages. Likewise, language is the key to the communication process in digital communication because of the limitations of non-verbal communication that cannot be included. Language may experience usage errors if it does not comply with existing spelling guidelines. Spelling is a writing system that describes a language and relates to the procedures for writing letters, words, absorption elements, and punctuation marks (Yakob \& Asra, 2019). Given this risk, Indonesian must be used properly so that the message's recipient can understand the message well. Indonesian is said to be good if it is used effectively and according to the existing context, and the correct Indonesian language follows the existing linguistic rules, PUEBI (Azizah, 2019). In Indonesia, grammar is guided by PUEBI (Pedoman Umum Ejaan Bahasa Indonesia) or The General Guidelines for Indonesian Spelling. PUEBI includes several things, including the use of letters and punctuation, word formation, writing absorption elements, and indexes (Yakob \& Asra, 2019).

\section{The Urgency of Using Emoji and PUEBI-Compliant Spelling in Digital Communication}

Emojis play an essential role in digital communication because people have limitations in conveying messages and expressions like direct communication. The results of this study indicate that the use of emoji helps convey messages and avoids the risk of misunderstanding because emojis can represent the user's emotions, expression, or state, convey messages and intentions, and give perceptions or impressions of the messages received. Nahwiyyah and Dewi (2020) also state that emojis represent expressions and substitutions for gestures, express emotions, and complement the intended message. Thus, as stated by Carman (in Rakhman, 2020), people tend to choose emojis representing their condition. A study found that messages accompanied by emojis had higher effectiveness than those not accompanied by emojis (Subkati, 2019). The reason is that written messages cannot create effective communication because of differences in perception between communicants and communicators, so that emojis are needed so that messages are easy to understand. 
The use of language in the communication process is also essential to convey messages. Likewise, language is the key to the communication process in digital communication because digital communication does not include elements of non-verbal communication. Language may experience usage errors if it does not conform to the existing linguistic rules. The linguistic rules in question include word selection (diction), language order or sentence sequences, appropriateness of the EYD (Enhanced Spelling) application, and the inclusion of punctuation marks (Irsasri \& Palupi, 2019).

According to Sulistyawati (2019), the use of language by millennial children tends to be wrong and does not follow PUEBI. Several language errors are found on social media, namely, spelling errors, usage diction errors, language structure errors, and the use of Indonesian variations in English, slang, and regional languages (Kholifah \& Sabardila, 2020). The use of good grammar needs to be applied in digital communication even though it is not formal because otherwise, a conflict or misunderstanding may occur.

The results of this study indicate that the use of emoji and proper spelling is critical in digital communication. The existence of emojis and the application of PUEBI-compliant spelling affect the smoothness of the communication process. Semantic barriers often found in digital communication are related to language factors and result in conflicts or misunderstandings due to different interpretations (Sahid, 2021). The same thing was conveyed by Triantoro (2019); Different interpretations of text messages sent in online communications can lead to misunderstandings. The use of emojis and proper spelling helps give the message intonation as this cannot be represented by text messages alone. The use of emoji can provide traits, complementary information, emphasis, opposition, representation, and the form of developing verbal messages. This statement aligns with Yuliarti's (2020) opinion, which explains that verbal communication is used to confirm the verbal communication conveyed, and possibly vice versa. That way, emoji can be used simultaneously with text or replace text messages as desired by the communicator (Al Azis, 2021).

Some examples of emojis in computer-based communication and their meanings are the folded hands emoji representing a prayer request or request, the laughing emoji reflecting humor, the arm emoji symbolizing enthusiasm, and the thumbs up emoji symbolizing approval (Afriani \& Azmi, 2020). In its use, emojis used repeatedly indicate an emphasis on the message conveyed (Oktario et al., 2019). People tend to use repeated emojis when they 
feel intense emotions, such as when they receive a funny message or express very uncomfortable feelings towards the person they are talking to. In addition, the use of emoji as a nonverbal language plays a role in influencing the flow and direction of the conversation and replaces the role of intonation and tone of speech that cannot be included in text messages (Maulidina, 2021). The presence of emojis in messages also makes communicants and communicators create a conversation according to their previous intentions, such as using folded hands emojis for formal communication. Communication will also be more exciting and messages more simple to understand when emoji are used in communication (Berlianty, 2020).

\section{The Role and Function of Emoji and PUEBI-Compliant Spelling in Digital Communication}

Little John \& Foss (in Nugroho \& Hasfi, 2019) argue that the type of language, emoji, and username used impact impression formation. The same thing is conveyed by Maulidina (2020), who states that emojis create a relaxed atmosphere and are a tool for channeling positive energy. In addition, emojis can give a particular impression on someone. The inclusion of emojis has an impact on the feedback generated by the communicant because messages that are not accompanied by emoticons can be considered as expressions of less friendly and can result in misunderstandings (Lokasari et al., 2019). In this study, respondents think that short messages, excellent or formal grammar or spelling, and without emojis give the impression that communicators are less friendly, indifferent, harsh, formal, or awkward. On the other hand, emojis can give a friendly and good impression to the communicant. A study stated that using emoticons/giphy/language style and the language used could give the impression of a communicator to the communicant (Nugroho \& Hasfi, 2019).

Punctuation marks used repeatedly have the function of giving more meaning or emphasizing to something, either certain emotions or feelings, such as the use of repeated exclamation points signifying annoyance or anger, and repeated question marks indicating a lack of understanding of something or the intention of being sarcastic (Arsanti \& Setiana, 2020). In this study, respondents claim that the intense use of capital letters gives an unfavorable impression, such as being less friendly and less flexible, angry, annoyed, or enthusiastic. Arsanti \& Setiana (2020) also mentions that capital letters are often used to emphasize something. 


\section{CONCLUSION}

Computer-based communication has facilitated human communication even though great distances separate them. Messages will arrive faster than direct communication and interaction. However, the message feature in computer-based communication has limitations; it cannot include nonverbal communication such as expressions and gestures like direct communication. Therefore, communication depends significantly on the use of written language only. However, computer-based communication is also accompanied by emoji features as a tool to convey and represent the sender's expression.

The existence of emojis and good spelling based on PUEBI plays a vital role in the digital communication process to facilitate sending and receiving messages or intentions; thus, the communication process runs smoothly amid existing limitations. In addition, the application of emoji and good spelling is crucial in preventing misunderstandings because emoji and the application of appropriate spelling can give intonation or tone of speech in messages, convey feelings, give a good impression to the sender, provide appropriate responses to the sender and the context of communication, and clarify and reinforce the message conveyed.

This research is still limited to the roles, functions, and perceptions of the use of emojis and good spelling based on PUEBI among adolescents represented by college students, so that the results of this study cannot be used to understand cases that occur in groups outside that age category. In addition, the respondents in this study are still relatively limited, so that they may not represent most of the data from the population. Therefore, it would be better if further research could expand the sample used or include other age groups to get a better perception or understanding. 